\title{
Water Quality Assessment of Amir Kabir Sugarcane Agro-industry with Respect to Agricultural and Drinking Views
}

\author{
Amin Banderi \\ MSc Student of Agroecology, Faculty of Agriculture, University of Birjand, Iran \\ E-mail: aminbanderi@gmail.com
}

\begin{abstract}
Mohammad Modarres Sheikh (Corresponding author)
MSc student of Environmental Pollutions

Faculty of Agriculture, University of Birjand, Iran

E-mail: m_modares66@yahoo.com
\end{abstract}

Hasan Hamdi

PhD. Head of Sugarcane Research Center

Sugarcane and By-products Development Co., Iran

E-mail: Hamdi.m@ irssct.com

Mahmoud Shomeli

Board of Science Sugarcane Research Center

Sugarcane Development and Side Industry, Iran

E-mail: eshomeli@gmail.com

\section{Ali Sheini Dashte Gol}

Master of Sugarcane Research Center, Sugarcane Development and Side Industry, Iran E-mail: sheinidashtegol@yahoo.com 
Received: September 9, 2012

Accepted: October 9, 2012

doi:10.5296/jee.v3i1.2353

URL: http://dx.doi.org/10.5296/jee.v3i1.2353

\begin{abstract}
Use of water with poor quality in agriculture not only leads to degradation of soil physical properties, which results in wastelands, but also reduces crops production and causes trouble for irrigation systems. In the other side, agriculture is known itself as a main water polluting sources. Health improvement of human community is not possible without access to safe drinking water.Considering this issue, developed countries have successfully dealt with their health problems, especially with respect to drinking water. In this way, a study was conducted at Amir Kabir Sugarcane Agro-industry to evaluate the chemical and physical properties of water of the Karun River from 2003 to 2011. All measured factors were compared with FAO irrigation water quality standards and drinking water standards of WHO. Based on results, TDS $\left(1408.25 \mathrm{mgl}^{-1}\right)$ was higher than allowable limit in all studied years. Also, TH factor showed a dramatic increase over WHO standard science 2007 due to drought condition; however, other factors were found to be at standard levels. Therefore, water of the region is not recommended for drinking. For irrigation purposes, only EC factor was beyond the permissible limit, which caused water quality to be placed in $\mathrm{C}_{3}$ class (high salinity). However, such water can be used to grow saline resistance crops provided adopting appropriate management practices.

It should be noted that current standards often developed for a given climatic conditions, which are completely different with studied area, and therefore should be exposed to reconsideration and revision.
\end{abstract}

Keywords: Irrigation, Water Hardness, Salinity, Electrical conductivity, Water use 


\section{Introduction}

Using fresh and newly harvested water has a priority for drinking, sanitation and industry purposes, but consumption of brackish and saline water as a source of irrigating water for agriculture can be considered as an important strategy and a national goal for sustainable development. Obviously, this water can be utilized under given conditions and to grow salt resistant crops, so calling them as undesirable water should be strongly avoided. On the other hand, excessive extraction of underground waters through deep and semi-deep wells and saltwater intrusion into freshwater aquifers, have caused more extension of saline water, as its volume is rising increasingly. The outlook of the water and irrigation based on recognition of the future situation is demonstrative of tending toward using unconventional water resources (drainage water, industrial and agricultural wastewaters, underground brackish water and seawater). Of course, using these unusual water resources has undesirable impacts on the soil physical characteristics, crop yield and environment; therefore it is necessary to adopt proper measures toward de-escalating its disadvantageous effects. In this regard maximum yield should not be thought, rather more emphasis must be put on economic yield (Kiani \& Kochak-Zadeh, 2002). The previous experiences indicate that water shortage in nature, especially in arid and semi-arid areas, is always associated with a reduction in water quality. To sustain crop yields, therefore, it is necessary to use underground saline water (or drainage brackish water) in these areas along with fresh water for irrigation (Kiani et al., 2006).

Behavior measurement and decision making about water quality based on collected data is one of important challenges against environmental engineers and hydrologists, due to various uncertainties existing in all levels, from sampling to evaluation and analyzing the results. There are standards for various contaminations and pollutants in drinking water represented by organizations such as the World Health Organization (WHO, 1993). Some factors such as variation of rivers water flow rate in time, accompanying with qualitative changes, limit extensive use of most of these standards. On the other hand, almost all standards, developed by any organization, have uncertainties inherently, because their values have obtained by extrapolating experimental data resulted from animal tests or case studies. So, it's necessary to look for updating and proper using of these standards based on prevalent condition. Comprehensive understanding from status and trends of variation in water quality is an essential precondition for optimizing formulation, evaluation and implementation of water quality standards and limits defined by different organizations. There are different methods and measures in literatures for evaluating the quality of drinking water and decision making about it. But it seems in all approaches, definitive decision has been made with comparing values of water quality parameters and considering standards represented by various organizations, and the uncertainties in all stages this process is ignored (Deshpande et al., 1996).

The drinking water not only should have a clear and non-turbid appearance, but also be desirable and safe chemically and microbiologically. High concentration of dissolved salts in water gives a salty taste to water and reduce tendency of consumers to use such water, so the fresh water is always high demanding (WHO, 1996). 


\section{Macrothink}

From an agricultural point of view, concentration of bicarbonate is a main factor affecting water quality. As carbonate concentration increases in irrigation water and or soil solution, some disorders in plant iron nutrition may take place and plants can suffer chlorosis (Kalbasi, 1995). Bicarbonate also can disturb iron transportation and partitioning in leaves by affecting iron inflow from apoplastic system into the cytoplasm through plasmalema (Han et al., 1998). Chlorides and sulfates are other important anions effective in the formation of saline soils. All chloride salts are high water soluble and thereby possess a severe toxicity. The higher soil and ground water salinity therefore, more chlorine they have (Tanji, 1990).

The electrical conductivity (EC) is another important factor determining water quality for irrigation. It is known that wheat seed yield and height is affecting by an EC of $0.5-2.5 \mathrm{dSm}^{-1}$. When EC rose to $4 \mathrm{dSm}^{-1}$, the number of grains per unit area reduced significantly. In general, wheat grain yield in saline condition was up to $\% 80$ lower than non-saline environments (Stephanand \& wall, 1997); however there is a great inter- and intra-species variation in response to salinity. For example in a greenhouse experiment on the effect of irrigating with saline water on growth, yield components and nutrient absorption in the three wheat cultivars (Sakra 8, Saka9, Saka 6), it was found that plant height, total dry matter accumulation, number spikes per plant, number of grains per spike in Sakra8 was significantly more than two other varieties (Lamsal et al., 1999). SAR is also one of the water quality parameters showing the rate of sodium absorption. As Hadas (1982) stated, a water with high sodium absorption ratio (SAR) can reduce stability of soil structure and ultimately result in low soil permeability and crop yield, due to dispersion and swelling of clay particles.

Research objectives are: 1-Study on Karun River water quality at scope Amir Kabir Sugarcane Agro-industry 2-The study of temporal changes in river water quality 3- River water quality assessment of agricultural and drinking purposes.

\section{Materials and Methods}

\subsection{Study Area}

This research has been conducted based on nine years collected data from 2003 to 2011at a local scale in Khuzestan province, which is located between longitudes ( $47^{\circ} 42^{\prime}$ to $50^{\circ} 39^{\prime} \mathrm{E}$ ), and latitudes $\left(29^{\circ} 58^{\prime}\right.$ to $\left.32^{\circ} 58^{\prime} \mathrm{N}\right)$. Water quality parameters of Karun River were recorded at Amir Kabir and Mirza Koochak Khan Sugarcane Agro-industries zone (Fig 1); these agro-industries cover more than 29000 hectares. Farmlands located in the west of Karun River and south of Ahwaz city. Most of region is lowland, with an altitude of 2-16 meters. 


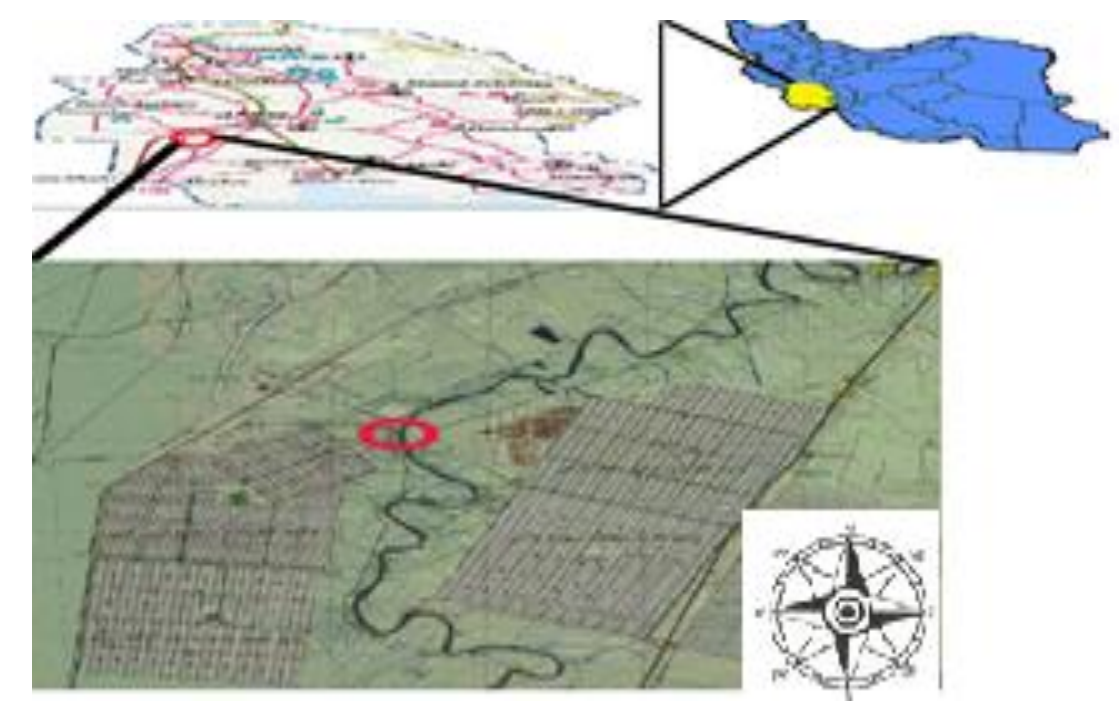

Figure 1. Geographical location of study area

\subsection{Method of Sampling and Moduling of Physical-chemical Parameters}

To determine water quality, water samples was taken from Karun water in place of pumping station Amir Kabir and the water drains in place out of the Agro-industry from the specified location in Figure 1, and after transferring to the laboratory were analyzed regarding physical and chemical parameters. Thus, the factors measured at average every week were converted into monthly means and at the end to annual means.

Analysis to measure the electrical conductivity, acidity, total dissolved solids, total hardness, sodium adsorption ratio, percent sodium solution, concentration of residual sodium, the anion (chloride and sulfate, carbonate and bicarbonate) and cations such as (sodium, magnesium, calcium).Among the parameters measured the amount of sodium by device flame photometer (Systronics k1/mk-III) at a wavelength of $589 \mathrm{~nm}$. Calcium, magnesium, bicarbonate and chloride were measured based on Titration Method. At the beginning, the drinking quality of water in the given area was evaluated. So that primarily standard table was prepared by WHO for drinking, then table was compared with the average amount factor of drinking during the years of 2003 to 2011. Consequently an exact and appropriate assessment was done. The appropriateness and inappropriateness of each factor was also recognised. Finally, statistical analysis was performed with SPSS and EXCEL statistical software. 
Table 1. Limit for drinking water quality related parameters, standard World Health Organization (WHO, 2004)

\begin{tabular}{|l|l|}
\hline Parameter & The maximum allowable \\
\hline $\mathrm{pH}$ & $7-8.5$ \\
\hline TDS & $500 \mathrm{mg} / \mathrm{l}$ \\
\hline $\mathrm{TH}$ & $500 \mathrm{mg} / \mathrm{l}$ \\
\hline $\mathrm{Ca}^{2+}$ & $200 \mathrm{mg} / \mathrm{l}$ \\
\hline $\mathrm{Mg}^{2+}$ & $150 \mathrm{mg} / \mathrm{l}$ \\
\hline $\mathrm{Cl}^{-}$ & $200 \mathrm{mg} / \mathrm{l}$ \\
\hline $\mathrm{SO}_{4}{ }^{2-}$ & $200 \mathrm{mg} / \mathrm{l}$ \\
\hline
\end{tabular}

Table 2. FAO standards for irrigation water (FAO, 1970)

\begin{tabular}{|c|c|c|c|}
\hline Water parameter & Symbol & Unit & Usual range in irrigation water \\
\hline Electrical Conductivity & $\mathrm{EC}$ & $\mathrm{dS} / \mathrm{m}$ & $0-3$ \\
\hline Total Dissolved Solids & $\mathrm{TDS}$ & $\mathrm{mg} / \mathrm{l}$ & $0-2000$ \\
\hline Cations and Anions & & & $0-20$ \\
\hline Calcium & $\mathrm{Ca}^{++}$ & $\mathrm{meq} / \mathrm{l}$ & $0-5$ \\
\hline Magnesium & $\mathrm{Mg}^{++}$ & $\mathrm{meq} / \mathrm{l}$ & $0-40$ \\
\hline Sodium & $\mathrm{Na}^{+}$ & $\mathrm{meq} / \mathrm{l}$ & $0 \_0.1$ \\
\hline Carbonate & $\mathrm{CO}^{2-}$ & $\mathrm{meq} / \mathrm{l}$ & $0-10$ \\
\hline Bicarbonate & $\mathrm{HCO}^{-}$ & $\mathrm{meq} / \mathrm{l}$ & $0-30$ \\
\hline Chloride & $\mathrm{Cl}^{-}$ & $\mathrm{meq} / \mathrm{l}$ & $0-20$ \\
\hline Sulphate & $\mathrm{SO}^{2-}{ }_{4}$ & $\mathrm{meq} / \mathrm{l}$ & $6.0-8.5$ \\
\hline MISCELLANEOUS & & & $0-15$ \\
\hline Acid/Basicity & $\mathrm{pH}$ & $1-14$ & $\mathrm{meq} / \mathrm{l}$ \\
\hline Sodium Adsorption Ratio & $\mathrm{SAR}^{2}$ & & \\
\hline
\end{tabular}

Agricultural purposes and irrigation were also determined based on methods of drinking. So, that primarily standard FAO table was prepared for agricultural purposes and average table values of the amount factors for agricultural purposes were accommodated with the standards FAO and appropriate and inappropriate factors were found. Sodium adsorption ratio (SAR) is a measure of the suitability of water for use in agricultural irrigation, as it can determine by the concentrations of solids dissolved in the water. It is also a measure of the sodality of soil, as it can determined from analysis of water extracted from the soil.

The formula for calculating sodium adsorption ratio is:

$\mathrm{SAR}=\frac{\mathrm{Na}^{+\mathrm{z}}}{\sqrt{\frac{\mathrm{Ca}^{+2}+\mathrm{Mg}^{+2}}{\mathrm{z}}}}$ 


\section{Macrothink}

Soluble Sodium Percent (SSP) is an index that defined as the ration of sodium to the total cation. When we have water with a SSP greater than \%60 it can cause a breakdown in the soil's physical properties (Khodapanah et al., 2009). SSP is expressed as follows:

SSP $=\frac{\text { Solub le } \mathrm{Na}^{+2} \text { Concentration }}{\text { Total Cations Concentration }} \times 100$

Where, all the ionic concentrations are expressed in meq/L.

The Residual Sodium Carbonate (RSC) is a kind of index used for irrigation water quality assessment. RSC is calculated as follows:

$\mathrm{RSC}=\left(\mathrm{CO}_{2}^{-3}+\mathrm{HCO}_{3}^{-}\right)-\left(\mathrm{Ca}^{2+}+\mathrm{Mg}^{2+}\right)$

Where, all the ions are expressed in meq/L.

\section{Results and Discussion}

\subsection{Assessment of Water Quality for Drinking}

Table 3. Results of Factor analysis for making use of drinking

\begin{tabular}{|l|l|l|l|l|}
\hline Parameter & Max & Min & AVERAGE & SD \\
\hline $\mathrm{pH}$ & 8.08 & 7.61 & 7.96 & 0.15 \\
\hline TDS & 7542.74 & 1017.08 & 1408.25 & 1960.21 \\
\hline $\mathrm{TH}$ & 750.61 & 369.54 & 476.11 & 118.18 \\
\hline $\mathrm{Ca}^{2+}$ & 7.64 & 3.85 & 5.09 & 1.18 \\
\hline $\mathrm{Mg}^{2+}$ & 7.47 & 3.60 & 4.60 & 1.20 \\
\hline $\mathrm{Cl}^{-}$ & 23.08 & 8.94 & 12.81 & 4.70 \\
\hline $\mathrm{SO}_{4}{ }^{2-}$ & 10.92 & 3.91 & 6.44 & 2.31 \\
\hline
\end{tabular}

Total dissolved solids (often abbreviated TDS) are a measure of all inorganic and organic materials in water. It is an important parameter for assessing groundwater quality. According to standard World Health Organization (WHO) limit can be of $500 \mathrm{mg} / \mathrm{l}$. In this study, the average rate during the 2003_2011 was $1408 / 25 \mathrm{mg} / \mathrm{L}$ which is higher than the standard. The results show that the water is not suitable for drinking. Some graphs were drawn to show the factors higher than normal. Then we could determine to what extent they violate the limit during different years. 


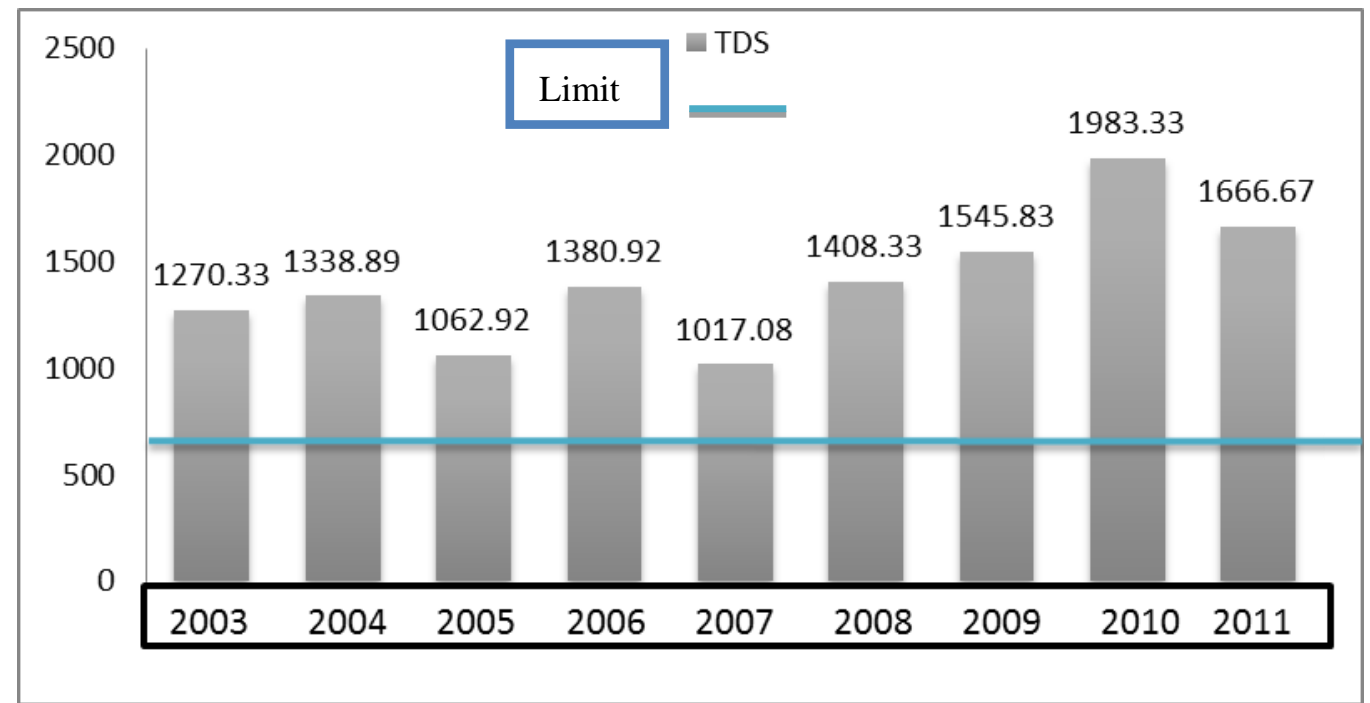

Figure 2. The TDS values are measured in years 2003-2011

The Figure 2 indicates that TDS levels are higher in all studied years, namely $500 \mathrm{mg} / \mathrm{l}$ has been demonstrated that the high soluble solids in case study. Total hardness of water is a measure of dissolved $\mathrm{Ca}^{2+}$ and $\mathrm{Mg}^{2+}$ in water expressed as $\mathrm{CaCO}_{3}^{-}$(Mitra et al., 2007). Standardized according to World Health Organization (WHO) limit $\mathrm{TH}$ can be500 mg/l, which is divided into the following table.

Table 4. TH values are classified according to WHO standards

\begin{tabular}{|l|l|}
\hline Type of water & TH \\
\hline soft & TH $<150 \mathrm{mg} / \mathrm{l}$ \\
\hline Relatively hard & $150<\mathrm{TH}<300 \mathrm{mg} / \mathrm{L}$ \\
\hline hard & $300<\mathrm{TH}<450 \mathrm{mg} / \mathrm{L}$ \\
\hline Very hard & $\mathrm{TH}>450 \mathrm{mg} / \mathrm{L}$ \\
\hline
\end{tabular}




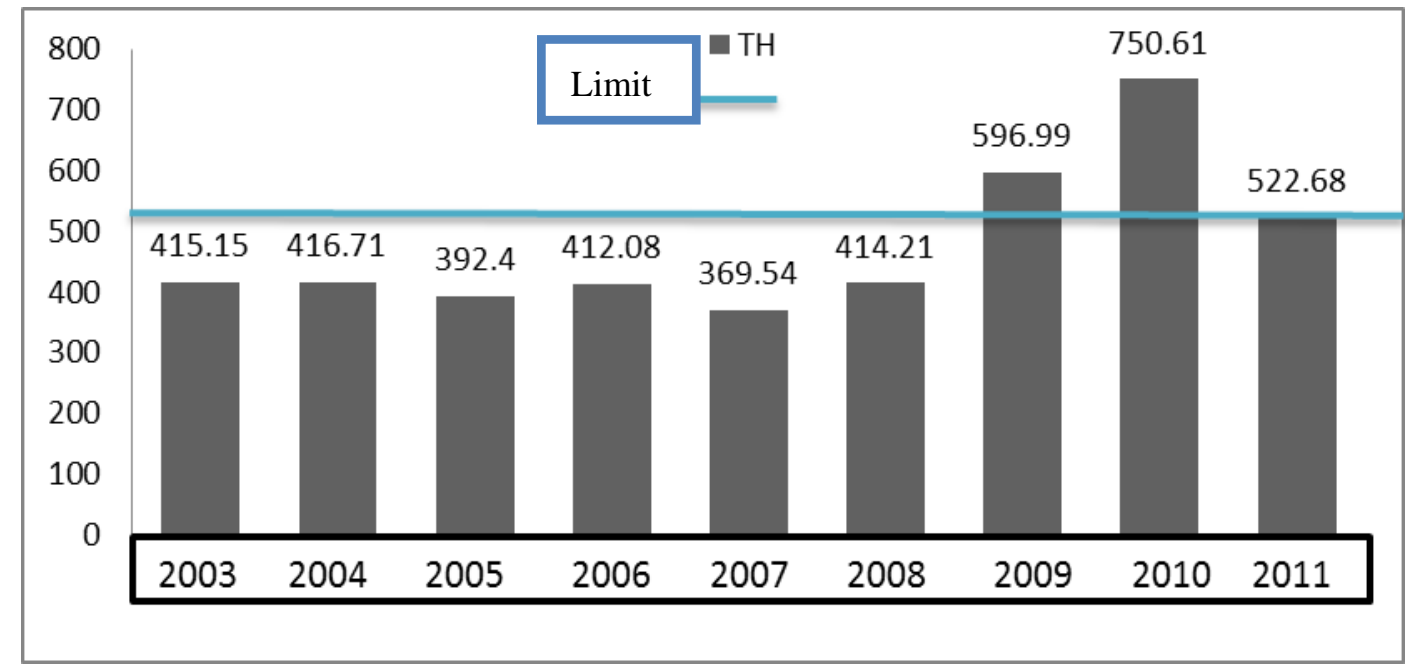

Figure 3. Values as measured for TH during the years 2003-2011

The table three shows that average amount of TH in 2003_2011, 476/11mg per liter that the class will be very hard. Figure 3 shows the amounts of TH to the end of 2008 lower than the limit but has been increased since 2008 and in early of 2009 in the amount of TH that it is due to the drought that in recent years has occurred, there has been attributed to the decreasing water level that increases the amount of solute. Limit for $\mathrm{CL}^{-}$and $\mathrm{SO}^{-2}{ }_{4}$ is $200 \mathrm{mg} / \mathrm{g}$. The average amount of them in 2003_2011, $\left(\mathrm{CL}^{-}\right)$8/12 and $\left(\mathrm{SO}^{2-}{ }_{4}\right)$ 44/6 are appropriate, $\mathrm{HCO}_{3}^{-}$ and $\mathrm{CO}_{3}^{2-}$ values are also allowed. The values of $\mathrm{PH}, \mathrm{Ca}^{2+}, \mathrm{Na}^{+}$and $\mathrm{Mg}^{2+}$ with respect to the standard WHO (World Health Organization) also are sufficient.

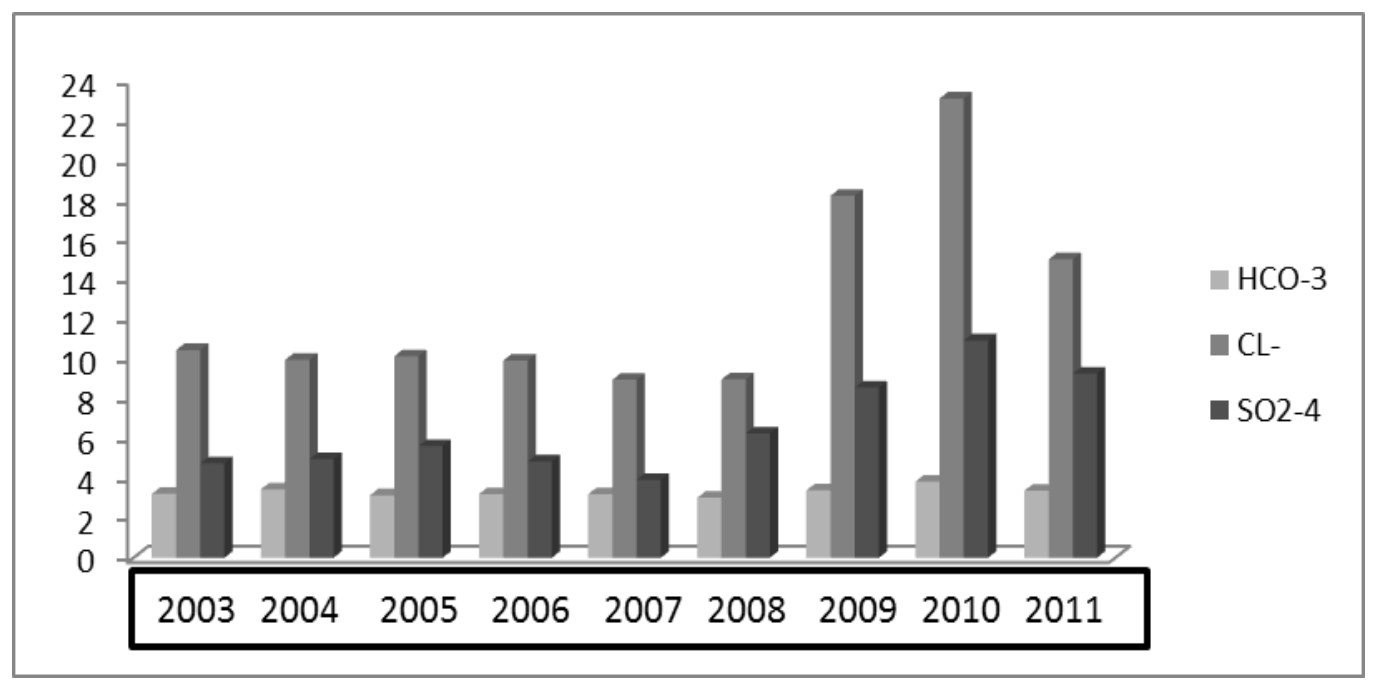

Figure 4. Average of $\mathrm{SO}_{4}^{2-}, \mathrm{CL}^{-}$and $\mathrm{HCO}_{3}^{-}$in the years 2003-2011 


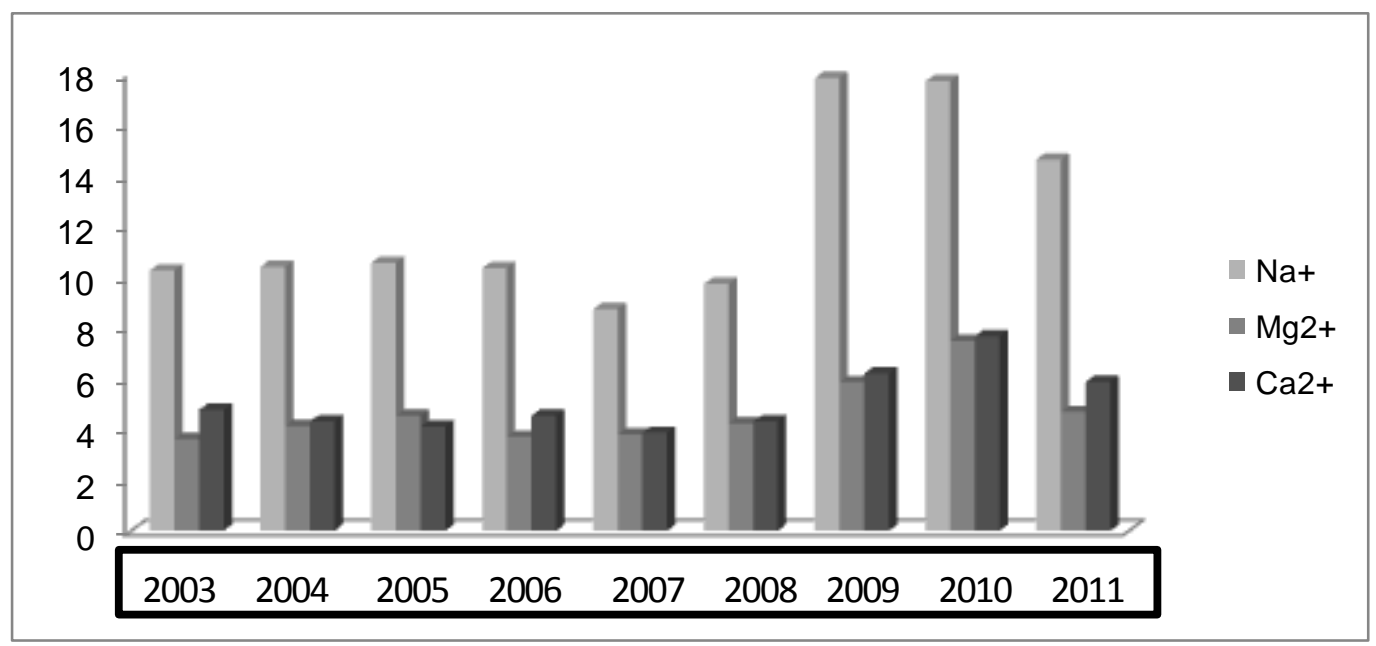

Figure 5. Average of $\mathrm{Ca}^{2+}, \mathrm{Mg}^{2+}$ and $\mathrm{Na}^{+}$in the years 2003-2011

Figures 4 and 5 indicates that both sodium and chloride anion, respectively are dominant in the region. With regard the result of table 3 and comparison with the standard of WHO and with notice that total hardness and dissolved solids have a very important role in the water quality for drinking purpose, nevertheless this water is not recommended for drinking. Some treatment methods such as reverse osmosis (RO) can be applied on water in order to adjust the level of factors.

Table 5. Assessment of water for drinking based on table Shuler

\begin{tabular}{|l|l|l|l|l|l|l|}
\hline $\begin{array}{l}\text { Paramet } \\
\text { er }\end{array}$ & Good & Acceptable & Average & Inappropriate & Quite unpleasant & $\begin{array}{l}\text { Non-potabl } \\
\text { e }\end{array}$ \\
\hline $\mathrm{PH}$ & 0 & $\% 11$ & $\% 89$ & 0 & 0 & 0 \\
\hline $\mathrm{Ca}^{2+}$ & $\% 100$ & 0 & 0 & 0 & 0 & 0 \\
\hline $\mathrm{Mg}^{2+}$ & $\% 100$ & 0 & 0 & 0 & 0 & 0 \\
\hline $\mathrm{Na}^{+}$ & $\% 100$ & 0 & 0 & 0 & 0 & 0 \\
\hline $\mathrm{TDS}$ & 0 & 0 & $\% 100$ & 0 & 0 & 0 \\
\hline $\mathrm{TH}$ & 0 & $\% 66$ & $\% 34$ & 0 & 0 & 0 \\
\hline $\mathrm{CL}^{-}$ & $\% 100$ & 0 & 0 & 0 & 0 & 0 \\
\hline $\mathrm{HCO}_{3}^{-}$ & $\% 100$ & 0 & 0 & 0 & 0 & 0 \\
\hline $\mathrm{SO}_{4}^{2-}$ & $\% 100$ & 0 & 0 & 0 & 0 & 0 \\
\hline
\end{tabular}

Table 5 indicates that the amounts of $\mathrm{Ca}^{2+}, \mathrm{Mg}^{2+}, \mathrm{Na}^{+}, \mathrm{CL}^{-}, \mathrm{HCO}_{3}^{-}$and $\mathrm{SO}_{4}^{2-}$ are $\% 100$ in Good and \%100 levels of TDS Average, \%89 of the values of PH Average and \%11 of the values acceptable and \%66 levels of TH acceptable and \%34 of the values are in average. 


\section{Macrothink}

\subsection{Quality Assessment for Agricultural Purposes}

The suitability of groundwater for irrigation is effects on both the plant and the soil (Khodapanah et al., 2009). Salts can limit growth of plants physically, and restricting the taking up of water through modification of osmotic processes, and is harmful for plant growth chemically by the effects of toxic substances upon metabolic processes. Analysis to measure the electrical conductivity, acidity, total soluble solids, total hardness, sodium adsorption ratio, percent sodium solution, concentration of residual sodium, the anion (chloride and sulfate, carbonate and bicarbonate) and cations such as (sodium, magnesium, calcium) was performed for evaluation of agricultural water. TDS is an important factor for agriculture water, the limit of concentration of TDS in groundwater for irrigation is $<3000$ $\mathrm{mg} / \mathrm{L}$ (Nagarajan et al., 2010). When we have TDS is $>3000 \mathrm{mg} / \mathrm{L}$, the risk to cause salinity maybe higher. The SAR formula can be derived of the proportion of sodium to calcium and magnesium, which affect the availability of the water for the crop (Singh, 2008). We have some criterion for SAR that is classified into excellent $(<10)$, good $(10-18)$, permissible (18-26), unsuitable (>26) (Khodapanah et al., 2009). RSC also be classified as suitable $(<1.25)$, marginal (1.25_2.5), and not suitable (>2.5) (Lloyd \& Heathcote, 1985). 


\section{Macrothink}

Table 6. Factors measured at years 2003-2011 for agricultural purposes

\begin{tabular}{|c|c|c|c|c|c|c|c|c|c|c|c|c|c|c|}
\hline $\begin{array}{l}\text { Different } \\
\text { years }\end{array}$ & RSC & $\mathrm{Ca}^{2+}$ & $\mathrm{Mg}^{2+}$ & $\mathrm{Na}^{+}$ & $\mathrm{SO}_{4}^{2-}$ & $\mathrm{CL}^{-}$ & $\mathrm{HCO}_{3}^{-}$ & $\mathrm{CO}_{3}^{2-}$ & SSP & SAR & $\mathrm{TH}$ & TDS & PH & $\mathrm{EC}$ \\
\hline 2003 & -5.13 & 4.75 & 3.60 & 10.23 & 4.75 & 10.44 & 3.21 & 0.00 & 54.51 & 5.03 & 415.15 & 1270.33 & 7.90 & 1.55 \\
\hline 2004 & -4.97 & 4.29 & 4.12 & 10.38 & 4.95 & 9.95 & 3.44 & 0.00 & 54.42 & 5.08 & 416.71 & 1338.89 & 8.05 & 1.66 \\
\hline 2005 & -5.48 & 4.10 & 4.52 & 10.53 & 5.61 & 10.13 & 3.14 & 0.00 & 54.76 & 4.99 & 392.40 & 1062.92 & 8.08 & 1.81 \\
\hline 2006 & -5.02 & 4.52 & 3.70 & 10.32 & 4.84 & 9.91 & 3.20 & 0.00 & 52.88 & 4.91 & 412.08 & 1380.92 & 8.05 & 1.53 \\
\hline 2007 & -4.44 & 3.85 & 3.78 & 8.71 & 3.91 & 8.94 & 3.19 & 0.00 & 53.87 & 4.50 & 369.54 & 1017.08 & 8.07 & 1.38 \\
\hline 2008 & -5.52 & 4.30 & 4.23 & 9.70 & 6.25 & 8.96 & 3.01 & 0.00 & 54.00 & 4.82 & 414.21 & 1408.33 & 8.01 & 1.48 \\
\hline 2009 & -8.63 & 6.18 & 5.84 & 17.79 & 8.55 & 18.19 & 3.38 & 0.00 & 58.73 & 7.21 & 596.99 & 1545.83 & 7.93 & 2.68 \\
\hline 2010 & -11.29 & 7.64 & 7.47 & 17.67 & 10.92 & 23.08 & 3.82 & 0.00 & 53.84 & 6.60 & 750.61 & 1983.33 & 7.61 & 3.06 \\
\hline 2011 & -7.15 & 5.85 & 4.67 & 14.59 & 9.25 & 15.00 & 3.37 & 0.00 & 55.54 & 6.25 & 522.68 & 1666.67 & 7.86 & 2.50 \\
\hline Average & -6.4 & 5.05 & 4.66 & 12.21 & 6.56 & 12.73 & 3.31 & 0.00 & 54.73 & 5.49 & 476.71 & 1408.26 & 7.95 & 1.96 \\
\hline
\end{tabular}


By studying the standards for agricultural water and comparing the mean factor studied in Table 6 with the standards, we can conclude that the above factors are of an acceptable value. So we can claim that the studied water is proper for agricultural purposes.

Table 7. Division EC and SAR values based on table Wilcox

\begin{tabular}{|c|c|c|c|c|}
\hline \multirow{4}{*}{ EC } & $\mathrm{C}_{1}$ & Low salinity & 0.1 to $0.25 \mathrm{EC}$ & $d s / m$ \\
\hline & $\mathrm{C}_{2}$ & average salinity & 0.25 to $0.75 \mathrm{EC}$ & $d s / m$ \\
\hline & $\mathrm{C}_{3}$ & High salinity & 0.75 to $2.25 \mathrm{EC}$ & $d s / m$ \\
\hline & $\mathrm{C}_{4}$ & Too much salt & $2 / 25$ to $5 \quad \mathrm{EC}$ & $d s / m$ \\
\hline \multirow{4}{*}{ SAR } & $\mathrm{S}_{1}$ & Low sodium & SAR 0 to 10 & \\
\hline & $\mathrm{S}_{2}$ & average sodium & SAR 10 to 18 & \\
\hline & $\mathrm{S}_{3}$ & High sodium & SAR18 to 26 & \\
\hline & $\mathrm{S}_{4}$ & Too much sodium & SAR 26 to 31 & \\
\hline
\end{tabular}

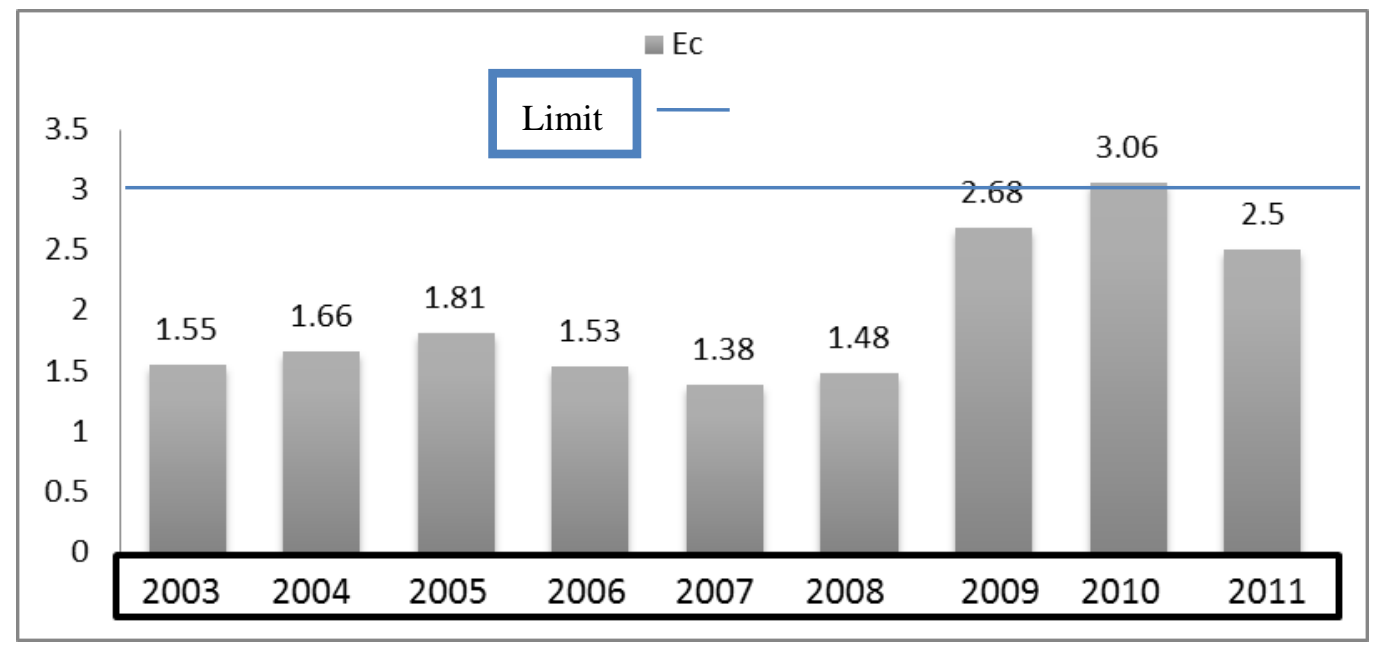

Figure 6. EC values measured in the years 2003_2011

As it can be seen the changes in EC in the Figure 6 have been between 0-3ds/m, it was only in 2010 shortly more than the limit the level has gone up, and its level in the middle of the years 2009_2010 had increased dramatically, which is due to the correlation between EC, TDS and TH. The relationship is shown below. Electrical conductivity and the concentration of total dissolved solids (TDS) to one ratio don't have a specific relationship. In dilute solutions (such as natural water) between these two factors is the following relationship.

$\mathrm{TDS}=0.5 \mathrm{EC}$

Total hardness, is the total concentration calcium and magnesium ions in water. As a result, water hardness, is a part of TDS. The main factor of sedimentation water is the water 


\section{Macrothink}

hardness. The EC is also an important factor for the water quality agricultural, show the rate of solubility of ion, which was compared the values in Table 7 for the EC with an average value over the years 2003_2011 that specified the amount of the EC in the third grade class C3 with the high salinity. Also, by comparing the average SAR over the years 2003_2011 with table 7, we can conclude that the SAR is classified in the first category, which has low sodium level. So we conclude that the class irrigation we are dealing with is $C_{3} S_{1}$ that just with a bundle of specific arrangements, is suitable for agriculture.

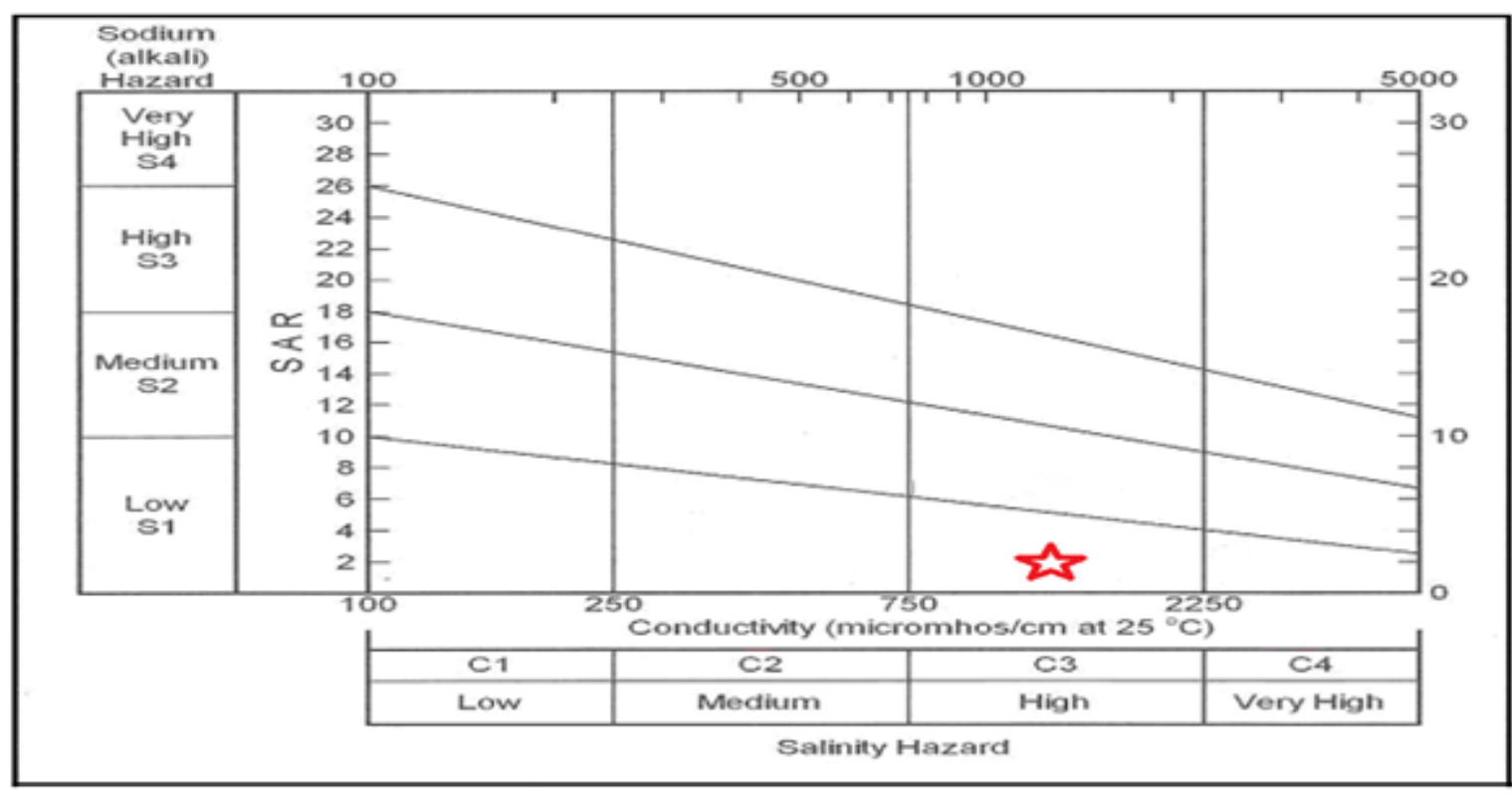

Represent the irrigation dass is desired

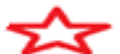

Figure 7. SAR and EC values of classification based on the chart Wilcox

Water quality and class-based classification be classified as Wilcox: $C_{1} S_{1}$ sweet, for agricultural perfect, $\mathrm{C}_{2} \mathrm{~S}_{1}, \mathrm{C}_{1} \mathrm{~S}_{2}, \mathrm{C}_{2} \mathrm{~S}_{2}$ little passion for agriculture is almost perfect, $\mathrm{C}_{1} \mathrm{~S}_{3}$, $\mathrm{C}_{2} \mathrm{~S}_{3}, \mathrm{C}_{3} \mathrm{~S}_{1}, \mathrm{C}_{3} \mathrm{~S}_{2}, \mathrm{C}_{3} \mathrm{~S}_{3}$ passion for farming with arrangements appropriate, $\mathrm{C}_{1} \mathrm{~S}_{4}, \mathrm{C}_{2} \mathrm{~S}_{4}, \mathrm{C}_{3} \mathrm{~S}_{4}$, $\mathrm{C}_{4} \mathrm{~S}_{4}, \mathrm{C}_{4} \mathrm{~S}_{3}, \mathrm{C}_{4} \mathrm{~S}_{2}, \mathrm{C}_{4} \mathrm{~S}_{1}$ very salty-harmful to agriculture. According to the FAO standard for EC between $0-3 \mathrm{dS} / \mathrm{m}$ but in the studied of Khuzestan province there are cultivated plants that can tolerate much higher salinity than we expect. It shows that the FAO standards are not absolute and are relative. 
Table 8. The salt tolerance of plants that are grown in Khuzestan province (Mass, 1990)

\begin{tabular}{|l|l|l|}
\hline $\begin{array}{l}\text { Degree of salt } \\
\text { tolerance }\left(\mathrm{S} . \mathrm{m}^{-1} \mathrm{~d}\right)\end{array}$ & Scientific name & Plant name \\
\hline 8 & Hordeumvulgare L & Barley \\
\hline 1.7 & Zeal mays L. & Corn \\
\hline 6.8 & Sorghum bicolor $(\mathrm{L})$. & Sorghum \\
\hline 1.7 & Saccharumofficinarum L. & Cane \\
\hline 6 & Triticumaestivum L. & Wheat \\
\hline 4 & Phoenix dactylifera L. & Date \\
\hline
\end{tabular}




\subsection{Results of Correlation test for factors}

Table 9. Results of the correlation between factors

\begin{tabular}{|c|c|c|c|c|c|c|c|c|c|c|c|c|}
\hline & Ec & $\mathrm{pH}$ & TDS & $\mathrm{TH}$ & SAR & SSP & RSC & $\mathrm{HCO}_{3}^{-}$ & $\mathrm{CL}^{-}$ & $\mathrm{SO}^{2-}{ }_{4}$ & $\mathrm{Na}^{+}$ & $\mathrm{Mg}^{2+}$ \\
\hline $\mathrm{pH}$ & $-.816^{* *}$ & & & & & & & & & & & \\
\hline TDS & $.840^{* *}$ & $-.879^{* *}$ & & & & & & & & & & \\
\hline $\mathrm{TH}$ & $.950^{* *}$ & $-.905^{* *}$ & $.906^{* *}$ & & & & & & & & & \\
\hline SAR & $.941^{* *}$ & $-.684^{*}$ & $.769^{*}$ & $.871^{* *}$ & & & & & & & & \\
\hline SSP & .505 & -.099 & .170 & .336 & $.723^{*}$ & & & & & & & \\
\hline RSC & $-.956^{* *}$ & $.885^{* *}$ & $-.876^{* *}$ & $-.992^{* *}$ & $-.869^{* *}$ & -.358 & & & & & & \\
\hline $\mathrm{HCO}_{3}^{-}$ & $.804^{* *}$ & $-.805^{* *}$ & $.770^{*}$ & $.859^{* * *}$ & $.672^{*}$ & .120 & $-.815^{* *}$ & & & & & \\
\hline $\mathrm{CL}^{-}$ & $.972^{* *}$ & $-.883^{* *}$ & $.862^{* *}$ & $.991^{* *}$ & $.902^{* *}$ & .406 & $-.987^{* *}$ & $.856^{* *}$ & & & & \\
\hline $\mathrm{SO}^{2-}{ }_{4}$ & $.957^{* *}$ & $-.844^{* *}$ & $.906^{* *}$ & $.929^{* *}$ & $.877^{* *}$ & .396 & $-.942^{* *}$ & $.715^{*}$ & $.924^{* *}$ & & & \\
\hline $\mathrm{Na}^{+}$ & $.977^{* *}$ & $-.766^{*}$ & $.825^{* *}$ & $.937^{* *}$ & $.985^{* *}$ & .611 & $-.937^{* *}$ & $.749^{*}$ & $.960^{* *}$ & $.920^{* * *}$ & & \\
\hline $\mathrm{Mg}^{2+}$ & $.918^{* *}$ & $-.811^{* *}$ & $.795^{*}$ & $.957^{* *}$ & $.805^{* *}$ & .326 & $-.976^{* *}$ & $.813^{* *}$ & $.950^{* * *}$ & $.890^{* * *}$ & $.885^{* *}$ & \\
\hline $\mathrm{Ca}^{2+}$ & $.951^{* *}$ & $-.931^{* *}$ & $.924^{* *}$ & $.987^{* *}$ & $.883^{* *}$ & .342 & $-.973^{* *}$ & $.839^{* *}$ & $.984^{* *}$ & $.936^{* *}$ & $.940^{* *}$ & $.906^{* * *}$ \\
\hline
\end{tabular}

Correlation is significant at the 0.05 level (1-taile) *.Correlation is significant at the 0.01 level (2-tailed) **.

Review table 9 shows that the factor EC has positive correlation at the level of $\% 1$ with all factors except, $\mathrm{pH}$ and $\mathrm{RSC}$, that this matter show that it spread with same source with the other factors in the environment. $\mathrm{pH}$ factor is also positively correlated only with the RSC factor at $\% 1$, but with factors TDS, TH, SAR, SSP, $\mathrm{CL}^{-}, \mathrm{SO}^{2-}{ }_{4}, \mathrm{HCO}_{3}^{-}, \mathrm{Na}^{+}, \mathrm{Ca}^{2+}, \mathrm{Mg}^{2+}$ has a negative correlation that this matter show that they have different source in the environment. The results also show that there is a negative correlation between TDS factor at the level of $\% 1$ with $\mathrm{RSC}$ and $\mathrm{pH}$, although it has a positive correlation with other factors. TH Factor not only correlation with factor SSP in the level of $\% 1$. Factor SAR has negative correlation with factor RSC and $\mathrm{pH}$. Also RSC has negative correlation with all factors. $\mathrm{HCO}_{3}^{-}, \mathrm{CL}^{-}$, $\mathrm{SO}^{2-}, \mathrm{Na}^{+}, \mathrm{Mg}^{2+}$ and $\mathrm{Ca}^{2+}$ factors, have positive correlation with all factors except $\mathrm{pH}$ and RSC. 


\section{Conclusion}

Water study area in terms of a series of chemical and physical factors was studied. Based on the analysis of the study area on water, this water for drinking according to the values of TDS, TH, it is not appropriate and not recommended because TDS and TH values are significantly above standard and based on shuler table they are placed in the averages and acceptable classes and none of them is classified in the good class and only with a series of steps like reverse osmosis (RO) system that reduced TH and TDS and finally usable. The performed assessment for agricultural purposes and according values to the TDS, SAR and RSC that have large role in determining the quality of irrigation water for agricultural purposes and the amounts of $\% 100$ of the TDS, SAR and RSC that are the lower limit. We can conclude that the water of studied area is suitable for agricultural purposes and water irrigation. However, for a long period usage, operations such as leaching with drainage, using resistant plants to salinity, can help to have an acceptable harvest, and maintain soil chemical and physical properties for a longer time.

\section{Acknowledgements}

The authors wish to thank the Amir Kabir Agro-industry for their financial help in this project and Dr. farzad Daliri for his English edition of this article.

\section{References}

Deshpande, A. W., Raje, D. V., \& Khanna, P. (1996b). "Agreement index for water consumption 1816-1820.". International conference eufit, Aachen,Germany, 2-5 sep., pp. 1818-1820.

Han, Z. H., T. Shen., R. F., Korcak, \& Baligar, V. C. (1998). Iron absorption by iron-efficient and inefficient species of apples. Jornal Plant Nutr, 21, 181-190. http://dx.doi.org/10.1080/01904169809365392

Kalbasi, M. (1995). Fe chlorosis in fruit trees. Isfahan University of technology press publication, 13. (in persian).

Khodapanah L., Sulaiman W. N. A., \& Khodapanah N. (2009). Groundwater quality assessment for different purposes in eshtehard district, tehran, iran. European Journal of Scientific Research, 36(4), 543-553.

Kiani, A., Kochak -Zadeh, M. (2002). Administrative and management strategies in the use of saline water, $1^{\text {st }}$ national conference on strategies to deal with water crisis, University of Zabol.

Kiani, A., M. Homaei, \& M. Mir Latifi. (2006). Evaluation of wheat yield loss functions in the combination of salinity and dehydration conditions. Journal of Soil and Water, 20(1), 73-82. 


\section{Al Macrothink}

Lamsal, K. N., Paudyal, G., \& Saeed, M. (1999). Model for assessing impact of salinity on soil water avalibility and crop yield. Agriculture water management, 41, 57-70. http://dx.doi.org/10.1016/S0378-3774(98)00116-4

Lloyd, J. W., \& heathcote, J. A. (1985). Natural inorganic hydrochemistry in relation to groundwater. Oxford university press, clarendon, pp. 294.

Maas, E. V. (1990). Crop salt tolerance. In k.k.tanji (ed.) Agricultural salinity assessment and management. Am. Soc. Civil eng. Manuals rep. Eng. Practice no. 71. Asce new York. P. 262-304.

Mitra, B. K., Sasaki C., Enari K., \& Matsuyama N. (2007). Suitability assessment of shallow groundwater for irrigation in sand dune area of northwest honshu island, japan. International journal of agricultural research, 2(6), 518-527.

Singh V., \& singhu. C. (2008). Assessment of groundwater quality of parts of gwalior (india) for agricultural purposes. Indian journal of science and technology, 1(4), 15.

Stephan, H., \& Wall, K. G. (1997). Grain yield from spring sown canadian wheat in saline rooting media. Can.jornal. Plant. Sci, 77(1), 63-68.

Tanji, K. K. (1990). Nature and extent of agricultural salinity. Chapter 1, IN Agricultural Salinity Assessment and Management K.K. Tanji, Editor, ASCE Manual No. 71, Amer. Soc. Civil Engrs. New York.

WHO. (1993). Guidelines for drinking water quality recommendation.Vol. I, world health organization, geneva, available at: http://www.who.int/water_sanitation_health/dwq /gdwq2v1/ en/index. html

WHO. (1996). Gvidelines for drinking water quality, 2nd ed, Jeneva. 